\title{
Tıp fakültesi öğrencilerinin aile planlaması ve cinsel yolla bulaşan hastalıklar ile ilgili sağlık bilgileri
}

\author{
Elif Okşan Çalıkoğlu ${ }^{1}$, Banu Bedir ${ }^{1}$, Sinan Yılmaz ${ }^{1}$, Ayşegül Aydın ${ }^{1}$ \\ ${ }^{1}$ Atatürk Üniversitesi Tıp Fakültesi Halk Sağlığı Ana Bilim Dalı, Erzurum, Türkiye
}

Health knowledge of medical students about family planning and sexually transmitted diseases

\section{ÖZET}

Giriş: Araşı̧ımamız Atatürk üniversitesi Tıp Fakültesi 1. ve 6. sınıf öğrencilerinde Aile Planlaması (AP) ve Cinsel Yolla Bulaşan Hastalıklar (CYBH) hakkındaki bilgi düzeylerini değerlendirmek amacıyla yapılmıştır.

Yöntem: Tanımlayıcı-kesitsel nitelikte olan araştırmamız 2014-2015 eğitim-öğretim yılında yürütülmüş olup, evreni Tıp Fakültesi birinci ve son sınıf öğrencileri oluşturmaktadır. Araştırmaya katılım \%76 olarak gerçekleşmiştir. Öğrencilere literatüre uygun olarak hazırlanan ve ön denemesi yapılmış bir anket formu yüz yüze görüşme tekniği ile uygulanmıștır. Verilerin analizinde tanımlayıcı istatistikler ve ki-kare testi kullanılmıştır.

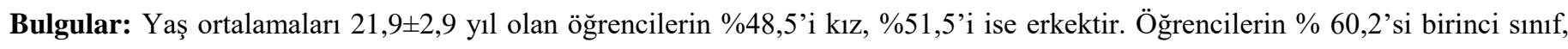
$\% 39,8$ 'i son sınıfta eğitim görmektedir. Birinci sınıf öğrencilerinin $\% 11,8$ 'i, son sınıfların $\% 29,5$ 'i AP tanımını doğru olarak belirtmiştir. Birinci sınıf öğrencilerinin \%40'1, son sınıfların ise \%68,2'si CYBH konusunda bilgisi olduğunu belirtmiştir.

Sonuç: AP tanımını ve CYBH konusunda bilgi düzeyi açısından birinci ve son sınıflar arasında anlamlı fark bulunmuştur. Öğrencilerin AP ve CYBH konusunda bilgi kaynağının sıklıkla sağlık personeli ve internet olduğu belirlenmiştir. Tıp fakültesi öğrencilerinin eğitim müfredatında AP ve CYBH konularına daha çok yer verilmesi, karşılaşılması olası sorunların üstesinden gelebilmeleri ve topluma yararlı olabilmeleri açısından önem arz etmektedir.

Anahtar kelimeler: tıp fakültesi, tıp öğrencisi, müfredat, aile planlaması, kontrasepsiyon, cinsel yolla bulaşan hastalıklar, sağlık bilgisi

\begin{abstract}
Introduction: To determine the level of knowledge about Family Planning (FP) and Sexually Transmitted Diseases (STD) in the first and sixth grade students of Atatürk University Medical Faculty.

Methods: This descriptive cross-sectional study was carried out in the academic year of 2014-2015 and the universe constitutes first and last year students of the Faculty of Medicine. Participation in the survey was 76\%. A questionnaire form prepared in accordance with the literature and pre-tested and the students was applied with face-to-face interview technique. In the analysis of the data, descriptive statistics and chi-square test were used.

Results: The average age of the students is $21.9 \pm 2.9 .48 .5 \%$ of the students are girls, $51.5 \%$ are males, $60.2 \%$ are first class and $39.8 \%$ are in last grade. $11,8 \%$ of first-year students and $29,5 \%$ of last-year students correctly stated the AP definition. $40 \%$ of firstyear students and $68.2 \%$ of last-year students said they had information about STDs.

Conclusion: There was a significant difference between the first and last classes in terms of the knowledge of FP definition and level of knowledge about STDs. It has been determined that the information resources of students about FP and STD are frequently health personnel and internet. It is important for medical faculty students to have more FP and STD issues in their education curriculum, to be able to overcome possible problems and to be helpful for the community.
\end{abstract}

Keywords: Medical faculty, medical student, curriculum, family planning, contraception, sexually transmitted diseases, health knowledge

Başvuru / Submission: Haziran / June 14, 2017

Kabul / Acceptance: Ağustos / Aug 01, 2017 Yazışma / Correspondence: Dr.Banu Bedir, Atatürk Üniversitesi Tıp Fakültesi Halk Sağlığı Ana Bilim Dalı, Erzurum, Türkiye

\begin{tabular}{|l|l|l|}
\hline E-MAIL & ORCID ID & DOI \\
\hline @ banubedir89@ hotmail.com & (D) orcid.org/0000-0001-8342-5351 & doi 10.22391/920.321473 \\
\hline
\end{tabular}

Atıf / Cite: Calikoglu EO, Bedir B, Yilmaz S, Aydin A. [Health knowledge of medical students about family planning and sexually transmitted diseases] Fam Pract Palliat Care. 2017;2(2):12-17 


\section{GíRiș}

Aile planlaması (AP); ailelerin istedikleri zaman bakabilecekleri, yetiștirebilecekleri, her bakımdan sorumluluklarını taşıyabilecekleri, kendi iradeleri dâhilinde çocuk sahibi olmaları anlamına gelmektedir(1). Bireylerin ya da eşlerin istenmeyen gebeliklerden sakınmalarına; iki doğum arasındaki süreyi düzenlemelerine, yaşlarını ve sosyoekonomik durumlarını göz önüne alarak ne zaman ve ne kadar çocuk sahibi olacaklarına karar vermelerine; çocuğu olmayan ailelerin çocuk sahibi olma isteklerini gerçekleştirmelerine yardım eden uygulamaların tümüdür(2). AP, temel sağlık hizmetleri içerisinde önemli bir yere sahiptir. Gebeliği önleyici yöntemlerin yeterli düzeyde kullanılmadığı durumlarda, pek çok sağlık ve sosyal sorunu beraberinde getirmektedir(3).

Üreme fonksiyonlarının geliştiği adölesan dönemi, AP ve cinsel yolla bulaşan hastalık (CYBH) kavramlarının da gündeme geldiği bir dönemdir. Adölesanlar, $\mathrm{CYBH}$ ve istenmeyen gebelikler ile bunlara bağlı gelişebilecek komplikasyonlar açısından risk altındadır(4). Hızlı nüfus artışı ve CYBH'lerin, özellikle de HIV enfeksiyonunun yayılımı ve şu an için başlıca korunma yolunun güvenli cinsel ilişki ve kondom kullanımı olması AP ve cinsellik konularının sürekli olarak gündemde kalmasına yol açmaktadır. Bu konularda hedef kitleyi oluşturan gençlerin konuya ilişkin bilgi tutum ve eğilimlerinin bilinmesi sorunun çözümü açısından önemlidir(5). CYBH gerek gelişmiş, gerekse gelişmekte olan ülkelerde önemli halk sağlığı sorunlarındandır. CYBH'lere maruz kalanların yaklaşık 1/3 kadarı 25 yaşın altındadır. Özellikle düşük gelir düzeyi olan kesimlerde daha sık görülmektedir(6).

CYBH; kişiden kişiye cinsel temas aracılığı ile geçen enfeksiyonlardır. Etken, kan, semen, diğer vücut sıvıları veya enfeksiyonlu vücut alanı ile direkt temas sonucunda geçmektedir. Yirmiden fazla CYBH ajanı bulunmaktadır. Klamidya, Trikomonas, Human Papilloma Virüs (HPV) enfeksiyonu, Sifiliz, Gonore, Kandida, Herpes, Hepatit B, Hepatit $C$ ve AIDS bu hastalıklardan bazılarıdır. Bilinen bir hayvan rezervuarı yoktur. Bu nedenle asemptomatik taşıyıcı kişiler en önemli kaynaktır(7). CYBH'ler; genellikle cinsel ilişki sonrası akut semptom ve bulgularla başlayıp sıklıkla kronikleşen infeksiyon hastalıkları olup önemli morbidite ve mortaliteye sebep olmaktadır(8). S1k görülmeleri, zor tanı konması ve tedavi edilmedikleri zaman ciddi komplikasyonlara yol açmaları nedeni ile insan sağlı̆̆ açısından çok önemli bir yere sahiptirler(9).

Çalışmada üniversitemizin Tıp Fakültesi 1. ve 6. sınıfta öğrenim gören öğrencilerin aile planlaması ve cinsel yolla bulaşan hastalıklar hakkındaki bilgi düzeylerinin saptanması amaçlanmıştır.

\section{YÖNTEM}

2014-2015 eğitim öğretim yılında gerçekleştirilen tanımlayıcı kesitsel nitelikteki çalışmamızın evrenini Atatürk Üniversitesi Tıp Fakültesi 274 birinci sınıf öğrencisi ve 150 altıncı sınıf öğrencisi oluşturmaktadır. Örneklem seçimi yapılmadan tüm öğrenciler çalışmaya dahil edilmiştir. Birinci sınıf öğrencilerinden 195, altıncı sınıf öğrencilerinden 129 kişi araştırmaya katılmayı kabul etmiştir. Araştırmaya katılım oran $1 \% 76$ 'dır.

Veri toplama aracı olarak literatür taranarak oluşturulan bir anket formu kullanılmıştır. Anket formu iki bölümden oluşmaktadır. Birinci bölümde sosyodemografik özelliklere ilişkin sorular, ikinci bölümünde AP ve CYBH'ye ilişkin sorular bulunmaktadır.

Katılımcılara araştırma ile ilgili bilgi verilip araştırmayı kabul edenlere anket formu uygulanmıştır. Çalışma için Atatürk Üniversitesi Tıp Fakültesi Girişimsel Olmayan Klinik Araştırmalar Etik Kurulu'ndan 20.02.2015 tarihli B.30.2.ATA.0.01.00/54 say1l etik kurul onayı ve gerekli idari izinler alınmıştır.

\section{İstatistiksel Analiz}

Veriler SPSS 20,0 (SPSS Inc, Chicago, Illinois) paket programında değerlendirildi, tanımlayıcı istatistiklerde sayı ve yüzde dağllımlar, ortalama \pm standart sapma verildi. İstatistiksel analizler ki-kare testi ile değerlendirilerek $\mathrm{p}<0,05$ değeri anlamlı kabul edildi.

\section{BULGULAR}

Araştırmada 324 katılımcının, yaş ortalaması 21,9 $\pm 2,9$ yıl, \% 60,2'si $(n=195)$ birinci sinıf, \%39,8'i $(n=129)$ son sinif öğrencisidir. Katılımcıların sosyodemografik özellikleri Tablo-1'de verildi.

Öğrencilere aile planlamasının tanımı sorulduğunda "'kişilerin istediği zaman istediği kadar çocuk sahibi olması", şeklinde doğru tanımlayanların $\% 11,8$ 'i birinci sınıf, $\% 29,5$ 'i ise son sınıf öğrencileri olup sınıflar arasında anlamlı fark vardir $(\mathrm{p}<0,001)$.

Araştırmaya katılan birinci sınıf öğrencilerinin $\% 42,1$ 'i, son sınıfların \%68,2'si emzirmenin bir aile planlaması yöntemi olmadığını bilmektedir ve sınıflar arasındaki fark istatistiksel olarak anlamlıdır $(\mathrm{p}<0,001)$.

Öğrencilerin aile planlaması ile ilgili sorulara verdikleri cevapların dağılımı Tablo-2'de gösterildi.

Fam Pract Palliat Care. 2017 Aug;2(2):12-17 
Tıp fakültesi öğrencilerinin aile planlaması ve cinsel yolla bulaşan hastalıklar ile ilgili sağlık bilgileri

İleride herhangi bir AP yöntemi kullanacakları konusunda tüm öğrencilerin \%60,2'si olumlu düşünmektedir. Tüm erkeklerin \%18,6’sı kondom, tüm kız öğrencilerin \%14,6’s1 hormonal kontraseptif yöntem tercih edeceğini bildirdi. Tüm öğrencilerin \%21,3'ü yöntemin tercih sebebinin yan etki olmaması, \%19,1'i ise kolay ulaşılabilir olması olduğunu ifade etti.

Aile planlaması yöntem seçiminde tüm öğrencilerin \%50,9'u sağlık personeli faktörünün önemli olduğunu, \%54,6's1 ise yöntem seçerken sağlık kuruluşundan bilgi almanın gerekli olduğunu bildirdi.
Öğrencilerin AP ile ilgili bazı sorulara verdikleri cevapların dağılımları Tablo-3'te gösterildi.

Birinci sınıf öğrencilerinin $\% 40,0{ }^{\prime} 1$ ile son sınıf öğrencilerinin \%68,2'sinin $\mathrm{CYBH}$ konusunda bilgilerinin yeterli olduğu düşüncesi gruplar arasında istatistiksel olarak anlamlı farklıyd $(\mathrm{p}<0,001)$.

Birinci sınıf öğrencilerinin \%44,6's1, son sınıf öğrencilerinin ise \%50,4'ü CYBH konularında bilgi edinme ihtiyaçlarının olduğunu bildirdi. Öğrencilerin $\mathrm{CYBH}$ ile ilgili sorulara verdikleri cevapların dağılımı Tablo-4'de gösterildi.

Öğrencilerin AP ve CYBH ile ilgili bilgi kaynaklarının dağılımı Tablo-5'te gösterildi.

Tablo 1. Öğrencilerin sosyodemografik özellikleri

\begin{tabular}{|c|c|c|c|c|}
\hline & 1.sinıf, $n(\%)$ & 6.sinıf, $n(\%)$ & $\mathbf{p}$ & $\mathbf{x}^{2}$ \\
\hline \multicolumn{5}{|l|}{ Cinsiyet } \\
\hline $\mathrm{K} 1 \mathrm{z}$ & $95(48,7)$ & $62(48,1)$ & \multirow{2}{*}{$\mathrm{p}=0,908$} & \multirow{2}{*}{$x^{2}=0,013$} \\
\hline Erkek & $100(51,3)$ & $67(51,9)$ & & \\
\hline \multicolumn{5}{|c|}{ Ailedeki çocuk sayısı } \\
\hline $1-2$ & $38(19,5)$ & $14(10,9)$ & \multirow{3}{*}{$\mathrm{p}=0,115$} & \multirow{3}{*}{$x^{2}=4,326$} \\
\hline $2-4$ & $74(37,9)$ & $53(41,1)$ & & \\
\hline 5 ve üzeri & $83(42,6)$ & $62(48,1)$ & & \\
\hline \multicolumn{5}{|c|}{ Annenin eğitim durumu } \\
\hline Okur-yazar değil & $24(12,3)$ & $9(7,0)$ & \multirow{5}{*}{$\mathrm{p}=0,260$} & \multirow{5}{*}{$x^{2}=5,272$} \\
\hline İlkokul & $52(26,7)$ & $47(36,4)$ & & \\
\hline Ortaokul & $34(17,4)$ & $23(17,8)$ & & \\
\hline Lise & $49(25,1)$ & $31(24,0)$ & & \\
\hline Üniversite & $36(18,5)$ & $19(14,7)$ & & \\
\hline \multicolumn{5}{|c|}{ Babanın eğitim durumu } \\
\hline Okur-yazar değil & $12(6,2)$ & $9(7,0)$ & \multirow{5}{*}{$\mathrm{p}=0,828$} & \multirow{5}{*}{$x^{2}=1,522$} \\
\hline İlkokul & $40(20,5)$ & $31(24,0)$ & & \\
\hline Ortaokul & $40(20,5)$ & $29(22,5)$ & & \\
\hline Lise & $54(27,7)$ & $29(22,5)$ & & \\
\hline Üniversite & $49(25,1)$ & $31(24,0)$ & & \\
\hline
\end{tabular}

Tablo 2. Öğrencilerin aile planlaması ile ilgili sorulara verdikleri cevapların dağılımı

\begin{tabular}{|c|c|c|c|c|}
\hline & 1.sınıf, $n(\%)$ & 6.sinıf, $n(\%)$ & $\mathbf{p}$ & $\mathbf{x}^{2}$ \\
\hline \multicolumn{5}{|l|}{ Aile planlamasının tanımı } \\
\hline Az çocuk sahibi olmak & $23(11,8)$ & $16(12,4)$ & \multirow{5}{*}{$\mathbf{p}<0,001$} & \multirow{5}{*}{$x^{2}=20,183$} \\
\hline Bakabileceği kadar çocuk sahibi olmak & $88(45,1)$ & $35(27,1)$ & & \\
\hline Nüfusu azaltmak & $31(15,9)$ & $17(13,2)$ & & \\
\hline Sağlıklı çocuk edinmek & $30(15,4)$ & $23(17,8)$ & & \\
\hline $\begin{array}{l}\text { Kişilerin istediği zaman istediği kadar çocuk sahibi } \\
\text { olması }\end{array}$ & $23(11,8)$ & $38(29,5)$ & & \\
\hline \multicolumn{5}{|l|}{ Emzirme bir aile planlaması yöntemi midir? } \\
\hline Evet & $113(57,9)$ & $41(31,8)$ & \multirow{2}{*}{$\mathbf{p}<0,001$} & \multirow{2}{*}{$x^{2}=21,314$} \\
\hline Hayır & $82(42,1)$ & $88(68,2)$ & & \\
\hline \multicolumn{5}{|l|}{ Küretaj bir aile planlaması yöntemi midir? } \\
\hline Evet & $66(33,8)$ & $34(26,4)$ & \multirow{2}{*}{$\mathrm{p}=0,153$} & \multirow{2}{*}{$x^{2}=2,041$} \\
\hline Hayır & $129(66,2)$ & $95(73,6)$ & & \\
\hline
\end{tabular}


Tablo 3. Öğrencilerin aile planlaması ile ilgili bazı sorulara verdikleri cevapların dağılımları

\begin{tabular}{|c|c|c|c|c|}
\hline & 1.sinıf, $n(\%)$ & 6.SInıf, $n(\%)$ & p & $\mathbf{x}^{2}$ \\
\hline \multicolumn{5}{|c|}{$\begin{array}{l}\text { Kadın tüp ligasyonu istiyorsa eşi karşı olsa bile } \\
\text { yaptırabilmeli }\end{array}$} \\
\hline Evet & $80(41,0)$ & $33(25,6)$ & & $x^{2}=8,15$ \\
\hline Hayır & $115(59,0)$ & $96(74,4)$ & & \\
\hline
\end{tabular}

Erkek vazektomi istiyorsa eşi karşı olsa bile yaptırabilmeli
Evet
$90(46,2)$
$39(30,2)$
Hayır
$105(53,8)$
$90(69,8)$
$\mathrm{p}=0,004$
$\mathrm{x}^{2}=8,213$

Çiftlerde yöntem kullanma sorumluluğu kadınındır
Evet $\quad 75(38,5)$
$17(13,2)$
Hayır $120(61,5)$
$112(86,8)$
$p<0,001$
$x^{2}=24,410$

Korunmak isteyen herkes aile planlaması yöntemine ulaşabilmeli

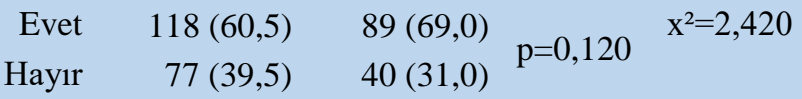

Liselerde cinsel konular ve aile planlaması hakkında bilgi verilmeli

$\begin{array}{rrr}\text { Evet } & 125(64,1) & 88(68,2) \\ \text { Hayır } & 70(35,9) & 41(31,8)\end{array}$ p=0,445 $\quad \mathrm{x}^{2}=0,584$

\section{TARTIŞMA}

AP ve CYBH konusunda tıp fakültesi öğrencilerinin bilgi ve farkındalık düzeyi, meslek hayatları boyunca toplum sağlığı üzerinde oynayacakları etkin rol açısından önem taşımaktadır. Araştırma kapsamına alınan 324 kişilik tıp fakültesi öğrencilerinin yaş ortalaması $21,9 \pm 2,9$ yıldır. AP tanımını doğru yapanların oranı birinci ve son sınıflar için sırası ile $\% 11,8$ ve $\% 29,5$ olup aralarında istatiksel olarak anlamlı fark vardır. Bu durum birinci sınıf öğrencilerinin henüz tıp eğitiminin başında olmalarından, Kadın Doğum Hastalıkları stajının ileriki sınıflarda alınmasından kaynaklanmış olabilir. Yıldırım'ın(10) üniversite öğrencilerinde yaptığı çalışmada AP tanımını doğru bilme durumu tıp fakültesi öğrencilerinde \%33,7 olarak bulunmuş ve bizim çalışmamız ile benzerdir. Kaynar ve ark.'nın(11) sağlık yüksekokulu öğrencilerinde yaptı̆̆ı çalışmada ise \%68,7'sinin AP tanımını doğru bildiği görülmüştür. Sağlık meslek yüksekokulu öğrencilerinde yüksek çıkması, araştırma grubundaki öğrencilerin sağlık meslek lisesi kökenli olması ve daha önceden sağlık eğitimi almış olmalarından kaynaklanabilir. Ege ve ark.'nın ebelik son sınıf öğrencilerinde yaptığı çalışmada AP eğitimi öncesinde bu oran $\% 6,9$ olup eğitim sonrasında $\% 93,1$ 'e yükseldiği görülmüştür(12).

Araştırmaya katılan öğrencilere ileriki yaşamlarında kontraseptif yöntem kullanma düşünceleri sorgulandığında erkeklerin \%18,6's1 kondom, k1zların \%14,6's1 hormonal kontraseptif kullanımını tercih edeceklerini belirtmişlerdir.

Tablo 4. Öğrencilerin CYBH ile ilgili sorulara verdikleri cevapların dağılımları

\begin{tabular}{|c|c|c|c|c|c|c|}
\hline & \multicolumn{2}{|c|}{ 1.sınıf, $n(\%)$} & \multicolumn{2}{|c|}{ 6.Sinıf, $n(\%)$} & $\mathbf{p}$ & $\mathbf{x}^{2}$ \\
\hline \multicolumn{7}{|c|}{ CYBH ile ilgili bilgi düzeyini yeterli hissetme } \\
\hline Evet & 78 & 40,0 & 88 & 68,2 & \multirow{2}{*}{$\mathrm{p}<0,001$} & \multirow{2}{*}{$x^{2}=24,742$} \\
\hline Hayır & 117 & 60,0 & 41 & 31,8 & & \\
\hline \multicolumn{7}{|c|}{ CYBH ile ilgili bilgi edinme ihtiyacı } \\
\hline Evet & 87 & 44,6 & 65 & 50,4 & \multirow{2}{*}{\multicolumn{2}{|c|}{$p=0,308 \quad x^{2}=1,039$}} \\
\hline Hayır & 108 & 55,4 & 64 & 49,6 & & \\
\hline \multicolumn{7}{|c|}{ CYBH ile ilgili toplantılara katılma isteği } \\
\hline Evet & 96 & 49,2 & 75 & 58,1 & \multirow{2}{*}{\multicolumn{2}{|c|}{$p=0,116 \quad x^{2}=2,472$}} \\
\hline Hayır & 99 & 50,8 & 54 & 41,9 & & \\
\hline \multicolumn{7}{|c|}{ CYBH cinsel ilişki dışında bulaşabilir } \\
\hline Evet & 127 & 65,1 & 86 & 66,7 & \multirow{2}{*}{\multicolumn{2}{|c|}{$p=0,775 \quad x^{2}=0,082$}} \\
\hline Hayır & 68 & 34,9 & 43 & 33,3 & & \\
\hline \multicolumn{7}{|c|}{ CYBH sağlıklı görünen kişilerden de bulaşabilir } \\
\hline Evet & 119 & 61,0 & 91 & 70,5 & \multirow{2}{*}{$\mathrm{p}=0,079$} & \multirow{2}{*}{$x^{2}=3,084$} \\
\hline Hayır & 76 & 39,0 & 38 & 29,5 & & \\
\hline \multicolumn{7}{|c|}{ CYBH durumunda doktora rahatlıkla başvurabilme } \\
\hline Evet & 109 & 55,9 & 79 & 61,2 & \multirow{2}{*}{$\mathrm{p}=0,340$} & \multirow{2}{*}{$x^{2}=0,910$} \\
\hline Hayır & 86 & 44,1 & 50 & 38,8 & & \\
\hline
\end{tabular}

Tablo 5. Öğrencilerin AP ve CYBH ile ilgili bilgi kaynaklarının dağılımı

\begin{tabular}{lrr}
\hline & Aile Planlaması & $\begin{array}{c}\text { Cinsel Yolla Bulaşan } \\
\text { Hastalıklar }\end{array}$ \\
\cline { 2 - 3 } Bilgi kaynağı & Sayı (\%) & Sayı (\%) \\
Kitap Dergi & $43(13,3)$ & $27(8,3)$ \\
Televizyon & $28(8,6)$ & $30(9,3)$ \\
İnternet & $84(25,9)$ & $72(22,2)$ \\
Aile & $29(9,0)$ & $28(8,6)$ \\
Arkadaş & $34(10,5)$ & $40(12,3)$ \\
Sağlık Personeli & $106(32,7)$ & $127(39,2)$ \\
\hline
\end{tabular}

Bilir ve ark.'nın(13) çalışmasında erkeklerin \%24,5'i Aydın'ın çalışmasında ise \%28,6'sı kondomu tercih edeceklerini belirtmişlerdir(14). Göz ve ark.'nın (15) evlilik öncesi genç kızlarda yürüttüğü bir çalışmada ileriki yaşamlarında hormonal kontraseptif yöntem kullanmayı düşünenlerin sıklığ1 \%22,1 bulunmuştur. Bizim sonuçlarımız da bu çalışmalar ile benzerdir. Kullanmayı düşündükleri AP yöntemini tercih nedenlerini öğrencilerin \%21,3'ü yan etkisi olmaması, \%19,1'i ise kolay ulaşılabilir olması olarak ifade etmiştir. Kaynar ve ark.'nın(11) çalışmasında ise bu oranlar sırası ile \%27,4 ve \%25,7 olarak bildirilmiş ve çalışmamızın sonuçları ile uyumludur.

Çalışmamızda öğrencilerin \%50,9'u AP yöntem seçiminde sağlı personeli faktörünün önemli rol oynadığını belirtmiştir. Akalper ve ark.(16), Kaynar ve ark.'nın(11) 
Tıp fakültesi öğrencilerinin aile planlaması ve cinsel yolla bulaşan hastalıklar ile ilgili sağlık bilgileri

yaptıkları iki farklı çalışmada da yöntem seçiminde, AP konularında eğitim almış sağlık personellerinin önemli rol oynadığı vurgulanmıştır.

Araştırmamızda CYBH konusunda tüm öğrenciler arasında $\% 48,8$ 'i yeterli bilgiye sahip olmadı̆̆ını, bu oranla tutarlı olarak \%46,9'u CYBH hakkında bilgi edinme ihtiyacı olduğunu bildirmiştir. Kara ve ark.'nın (17) Ankara'daki bir bölgede gençlerde yaptığı çalışmanın sonuçları da çalışmamızı destekler niteliktedir. İlgün ve ark.'nın(18) üniversite öğrencilerinde yaptığı çalışmada CYBH'ı bilme oranı \%48,2 bulunmuştur. Elkin ve ark.'nın (19) üniversite öğrencilerinde yaptığı çalışmada CYBH konusunda bilgisinin yeterli olduğunu belirtenler \%42,6 ve bilgi almak isteyenler \%73 olarak bildirilmiştir. Akalper ve ark.(16) ise CYBH konusunda bilgi almak isteyenlerin sıklığını \%77,1 bulmuştur. Araştırma grubumuzun tıp fakültesi öğrencilerinden oluşması, bizim çalışmamızdaki bilgi almak isteyenlerin sıklığının bu çalışmalara göre düşüklüğünü açıklayabilir.

Çalışmamızda öğrencilerin \%29,9'u AP hizmetlerinin ihtiyaç duyan herkese verilmesi gerektiği görüşündedir. Bir çalışmada kişiler eğitimden önce "sadece evli çiftler ve kadınlara" eğitimden sonra ise "ihtiyaç duyan herkese", AP hizmetlerinin sağlanması gerektiğini belirtmiştir(12). Kadıŏlu ve ark.(20) çalışmasında cinsel eğitimin yalnızca evliliğe hazırlanan çiftlere değil tüm topluma verilmesinin doğru olacağını bildirilmiştir. Bu sonuçlar da çalışmamızı destekler niteliktedir.

Öğrencilerimizin $\% 71,6$ 's1 aile planlaması yöntemi kullanımında çiftlerin eşit derecede sorumlu olduğunu belirtmiştir. Taşçı'nın (21) çalışmasında bu oran \%87,1 olup çalışmamızı desteklemektedir.

Çalışmamızdaki öğrencilerin \%30,9'u kürtajı bir AP yöntemi olarak değerlendirmiştir. Yurdakul ve ark.(22) ise bu oranı \%27 olarak bildirmiştir. Babadağlı ve ark.'nın(23) batı bölgesindeki bir hastanede doğurganlık dönemindeki kadınlarda yaptığı çalışmada bu oran \%11 olarak bulunmuştur. $\mathrm{Bu}$ oranın bizim çalışmamıza göre düşük çıkması bölgesel farklılıktan kaynaklanmış olabilir.

Emzirmeyi bir AP yöntemi olarak değerlendirenlerin oranı $\% 47,5$ olup birinci ve son sinıflar arasındaki fark istatistiksel olarak anlamlıdır. Emzirme belli ölçütlere uyulduğu takdirde oldukça etkili bir gebeliği önleyici yöntem olarak kullanılabilmektedir. Dünya Sağlık Örgütü (DSÖ) ve uluslararası kuruluşlar tarafından Ağustos 1988'de İtalya'nın Bellogo kentinde yapılan bir konferansta, emzirmenin gelişmiş ve gelişmekte olan ülkelerde tüm anne ve çocuk sağlığı programlarında aile planlaması yöntemi olarak kabul edilmesine karar verilmiştir. Emzirme süresince fertilizasyonun geri dönüşünü etkileyen faktörler; menstrüasyonun geri dönmesi, emzirme durumu ve doğumdan itibaren geçen süredir. Bu koşulların sağladığı durumlarda emzirme \%98-99,5 etkili bir yöntem olmaktadır.
Son sınıf öğrencilerinde emzirmeyi bir AP yöntemi olarak kabul etmeyenlerin oranının yüksek olması; stajlarda eğitmenler tarafından geleneksel bir yöntem olan emzirmenin ilk 6 ay içinde daha etkili olmakla beraber kontraseptif yöntem olarak tek başına güvenilir olmadığının ve modern AP yöntemlerinden birine başvurulması gerekliliğinin belirtilmesi ile açıklanabilir.

Araştırmamıza katılan öğrencilerin AP ve CYBH ile ilgili en sık bilgi kaynaklarının sağlık personeli ve internet olduğu görülmektedir. Dokuz Eylül Üniversitesi'nin çalışmasına göre ilk sıradaki bilgi kaynağı \%73,3 ile arkadaş olarak bildirilmiştir(24). Lise öğrencilerinde yapılan bir çalışmada $\% 63,6$ oranında medya ve \%50,5 oranında arkadaşlardan bilgi edinildiği görülmüştür(25). Pınar, Tüzün ve Özalp’ın yaptıkları çalışmalarda bilgi kaynaklarının çoğunu yazılı ve görsel kaynaklar oluşturmakta iken Kara ve ark.'nın çalışmasında sağlık çalışanlarının oranı \%24,5'dir(17, 2628). Aslan ve ark.'nın(29) çalışmasında \%61,3 ve Kadığlu ve ark.'nın(20) çalışmasında ise \%42 oranında bilgi kaynağının internet olduğu görülmüştür. Konu ile ilgili literatür incelendiğinde adölesanlarda yapılan çalışmalarda en önemli bilgi kaynağının okul ve aileden alınan eğitim olduğu görülmektedir (30). Çalışmamızda ilk sırayı sağlık personellerinin almış olmasının sebebi Toplum Sağlığı Merkezleri'nin kurulması ile birlikte birinci basamakta okul sağlığı hizmetlerinde sağlık personellerinin aktif rol alması olabilir.

Öğrencilerimizin \%65,7'si liselerde cinsel konularla ilgili bilgi verilmesi görüşündedir. Yapılan bir çalışmada ilk cinsel ilişki deneyiminin ortalama 18 yaş olması nedeni ile AP ve CYBH konusundaki eğitimlerin ortaöğretimde verilmesi gerektiğinin önemi vurgulanmıştır(18). Elkin'in(19) çalışmasında ise öğrencilerin \%54,2'si liselerde eğitim vermenin doğru olacağını belirtmiştir.

\section{SONUÇ}

Gençlik dönemi üreme sağlığına ilişkin problemlerin ve CYBH'nin sık görüldüğü bir dönem olması sebebiyle önem arz etmektedir. AP ve CYBH konusunda son sinif tıp öğrencilerin bilgi düzeyi birinci sınıf öğrencilerinden yüksek bulunsa da yeterli bilgiye sahip olmadıkları görülmektedir. Tıp fakültesi öğrencilerinin ileriki meslek hayatlarında AP ve CYBH konusunda danışmanlık hizmeti verecek birincil kişiler olacakları düşünülürse eğitim müfredatlarında bu konuya daha çok yer verilmesi gerekmektedir.

Çıkar çatışması: Yoktur.

Finansal destek: Yoktur. 


\section{KAYNAKLAR}

1. Altundaş F, Mayda AS. Bolu Dörtdivan ilçesi'nde aile planlaması hizmetlerinin değerlendirilmesi. Düzce Üniversitesi Sağlık Bilimleri Enstitüsü Dergisi. 2011;1(1):1-7.

2. Ertop N, Altay B. 15-49 Yaş Arası Evli Kadınların Kullandıkları Aile Planlaması Yönteminin Eş Uyumuna Etkisinin İncelenmesi. KÜ Tip Fak Dergisi. 2012;14(3):1-8.

3. Koç G, Akın A, Özvarış ŞB. Hacettepe Üniversitesi Diş Hekimliği Fakültesi 1. Sınıf Öğrencilerinin Aile Planlamasına İlişkin Bilgileri. 3 Uluslararası Üreme Sağlı̆̆ ve AP Kongresi Ankara20-23 Nisan 2003. p. 165-6.

4. Ekuklu G, Tokuc B. Trakya Üniversitesi Tıp Fakültesi Öğrencilerinin HIV/AIDS Konusundaki Bilgi Düzeyleri ve Tutumları. Turkiye Klinikleri Journal of Medical Sciences. 2009;29(6):1598-604.

5. WJ. K, Jr. CW. The epidemiology and prevention of sexually transmitted diseases. The Urologic clinics of North America. 1992;1(1).

6. Workowski KA, Berman S. Sexually Transmitted Diseases Treatment Guidelines, 20102010.

7. Brandt AM. Sexually-Transmitted Disease - Shadow on the Land, Revisited. Ann Intern Med. 1990;112(7):4813.

8. Peaceman AM, Gonik B. Sexually transmitted viral disease in women. Postgrad Med. 1991;89(2):133-40.

9. Yıldırım T. Üniversite çağındaki ergenlerin cinsel bilgi, tutum ve davranışları. Edirne: Trakya Üniversitesi 2008.

10. Kaynar B, Beydağ KD, Özer FG. Sağlık yüksekokulu öğrencilerinin kullanmayı düşündükleri aile planlaması yöntemleri ve yöntem seçimini etkileyen faktörler. Fırat Sağlık Hizmetleri Dergisi. 2008;3(8):21-33.

11. Ege E, Timur S, Zincir H. Ebelik son sınıf öğrencilerinin aile planlaması eğitimi etkinliğinin değerlendirilmesi. Sürekli Tıp Eğitimi Dergisi. 2005;14(9):202-7.

12. Bilir N, Özcebe H, Vaizoğlu S. Van ili merkez ilçesi kentsel kesim nüfusunda 15-24 yaş arası kadınların ve erkeklerin üreme sağlığı ile ilgili bazı davranışlarının belirlenmesi, IX. Ulusal Halk Sağlığı Kongresi Bildiri Özet Kitab1, Ankara. 2004:257.

13. Aydın İ. Sağlık Yüksekokulunda okuyan öğrencilerin kullanmayı düşündükleri aile planlaması yöntemleri ve yöntem seçimini etkileyen faktörler. Hemşirelik Forumu Dergisi. 2003;6(1):28-32.

14. Göz F, Babadağlı B, Altınsoy N, Yıldızoğlu İ. Evlilik öncesi dönemdeki genç kızların aile planlaması ile ilgili bilgi ve düşünceleri. Journal of Anatolia Nursing and Health Sciences. 2005;8(3):47-55.

15. Akalpler Ö, Eroğlu K. Kuzey Kıbrıs Türk Cumhuriyeti'nde Üniversite Öğrencilerinin S1k Görülen Cinsel Yolla Bulaşan Enfeksiyonlara İlişkin Bilgileri ve Cinsel Davranışları. Hacettepe Üniversitesi Hemşirelik Fakültesi Dergisi. 2015;2(2):1-19.

16. Kara N, Demir H, Taşar MA, Dallar YB. Ankara'da düşük sosyoekonomik düzeyi olan bir bölgede ergenlerin cinsel yolla bulaşan hastalıklar hakkındaki bilgi düzeyleri. Türkiye Çocuk Hastalıkları Dergisi. 2014;9(1).

17. İlgün M, Dündar P. Celal Bayar Üniversitesi'nde bir grup öğrencinin aile planlaması ve cinsel yolla bulaşan hastalıklar konusundaki bilgi düzeyleri. TSK Koruyucu Hekimlik Bülteni. 2005;4(2):66-78.

18. Elkin N. Üniversite Öğrencilerinin Cinsel Yolla Bulaşan Hastalıklar Konusunda Bilgilerinin Araştırılması. Mersin Üniversitesi Sağlı Bilimleri Dergisi. 2015;8(1):1-14.

19. Kadığlu H, Yıldız A, Ercan N, Ergun A. Üniversite öğrencilerinin cinsellik ve cinsel eğitim ile ilgili goruşleri. Sürekli Tıp Eğitimi Dergisi. 2008;17(3):32-7.

20. Taşçı KD. Sağlık Memurluğu Öğrencilerinin Erkeğe Yönelik Aile Planlaması Yöntemlerini Kullanmaya İlişkin Görüşleri. Journal of Anatolia Nursing and Health Sciences. 2007;10(1).

21. Yurdakul M, Vural G. Etki derecesi sınırlı yöntem kullanma nedenleri ve hemşirenin aile planlaması hizmetlerinde etkinliği. Sağllk ve Toplum 2001;11:42-5.

22. Babadağlı B, Şahin S. Sakarya Doğum ve Çocuk Bakımevi ile SSK İzmit Hastanesi'nde Doğurganlık Dönemi Kadınların Aile Planlaması ve Danışmanlığı Konusunda Bilgi ve Tutumlarının Karşılaştırılması. Fırat Sağlık Hizmetleri Dergisi. 2006;1(2):51-64.

23. Ozan S, Aras Ş, Semin S, Orçin E. Dokuz Eylül Üniversitesi Tıp Fakültesi Öğrencilerinin Cinsel Tutum ve Davranış Özellikleri. DEÜ Tıp Fakültesi Dergisi. 2004;18(1):27-39.

24. Kapamadzija A, Bjelica A, Segedi D. Sex knowledge and behavior in male high school students. Medicinski Pregled. 2000;53(11-12):595-9.

25. Pınar G, Doğan N, Ökdem Ş, Algıer L, Öksüz E. Özel bir üniversitede okuyan öğrencilerin cinsel sağlıkla ilgili bilgi tutum ve davranışları. Tıp Araştırmaları Dergisi. 2009;7(2):105-13.

26. Tüzün H, İlhan F, Ceyhan MN, Maral I. Bir tıp fakültesi birinci sınıf öğrencilerinin aile planlaması ve cinsel yolla bulaşan hastalıklar konusundaki bilgi ve tutumları. J Turk Soc Obstet Gynecol. 2005;2(3):197-203.

27. Özalp S, Tanır HM, Ilgın H. Eskişehir Osmangazi Üniversitesi Tıp ve Mühendislik Fakültesi Öğrencilerinin Cinsel Yolla Bulaşan Hastalıklar ve Aile Planlaması Konusundaki Bilgi ve Tutumlarının Değerlendirilmesi. Duzce Medical Journal. 2011;14(3).

28. Aslan E, Bektaş H, Başgöl Ş. Üniversite Öğrencilerinin Cinsel Sağlık Konusundaki Bilgi Düzeyleri ve Davranışları. STED. 2014;23(5):174-82.

29. Clark LR, Jackson M, Allen-Taylor L. Adolescent knowledge about sexually transmitted diseases. Sexually transmitted diseases. 2002;29(8):436-43.

30. Obiechina NJ, Diwe K, Ikpeze OC. Knowledge, awareness and perception of sexually transmitted diseases (STDs) among Nigerian adolescent girls. Journal of Obstetrics and Gynaecology. 2002;22(3):3025. 